\title{
Interleukin 14 Measurement
}

National Cancer Institute

\section{Source}

National Cancer Institute. Interleukin 14 Measurement. NCI Thesaurus. Code C74810.

The determination of the amount of interleukin 14 present in a sample. 